Pontifícia Universidade Católica DO RIO DE JANEIRO

Pós-Graduação Lato Sensu em Língua Inglesa

Ana Flavia Quirino Ramos

Why do some Students Insist on Speaking Portuguese during an EFL Class? An Exploratory Practice Experience

Rio de Janeiro

Setembro 2018 
Pontifícia Universidade Católica

Ana Flavia Quirino Ramos

Why do some Students Insist on Speaking Portuguese during an EFL Class? An Exploratory Practice Experience

Monografia apresentada aoprograma de Pós Graduação em Letras da PUC-Rio como requisito parcial para obtenção do título de especialista em Língua Inglesa.

\section{Orientadora:}

Prof ${ }^{a}$ Maria Isabel Azevedo Cunha

Rio de Janeiro

Setembro 2018 


\section{Acknowledgements}

First and above all I would like to thank the Almighty God for all the incredible blessings He has been giving me so far.

My special thanks to my family for the support and incentive they gave me throughout the course.

I would like to express my deep gratitude to my advisor Professor Maria Isabel A. Cunha for her guidance, encouragement, and assistance.

My gratitude is also extended to the Professors Inés K. Miller and Clarissa Xavier Ewald as well as the Exploratory Practice group at PUC-Rio.

I would like to offer my special thanks to all the professors and classmates for their kindness and dedication at the Especialização em Língua Inglesa course.

I would like to deeply thank my students and my coordinator Silvia D’Ávila for all the support, patience and comprehension in our journey. 
Ramos, Ana Flavia Quirino; Cunha, Maria Isabel Azevedo (Advisor). Why do some Students Insist on Speaking Portuguese during an EFL Class? An Exploratory Practice Experience. Rio de Janeiro, August 2018, 36 p. Monograph - Departamento de Letras, Pontifícia Universidade Católica do Rio de Janeiro.

\begin{abstract}
The condition of English as a língua franca has been pushing more and more students of different age groups into classrooms worldwide and many of these learners face difficulties when learning English as a foreign Language (EFL) especially regarding the speaking skill, which ends up making them resort to their first language during the class. In this paper, after the formulation of the puzzles "Why do some students insist on speaking Portuguese during an EFL class?" and "How do I feel when I speak English?", Exploratory Practice (EP) was a tool used to collect the data through the use of Potentially Exploitable Pedagogic Activities (PEPAs). In order to analyze the data, Grounded Theory was used. With this study, other professionals could also reflect on similar questionings and might bring up other puzzles that could complement this study.
\end{abstract}

Keywords: English as a Foreign Language, Exploratory Practice, Potentially Exploitable Pedagogic Activities, speaking, students. 
Ramos, Ana Flavia Quirino; Cunha, Maria Isabel Azevedo (Orientadora). Por que alguns alunos insistem em falar Português durante uma aula de Inglês como língua estrangeira? Uma experiência de Prática exploratória. Rio de Janeiro, agosto de 2018, 36 p. Monografia - Departamento de Letras, Pontifícia Universidade Católica do Rio de Janeiro.

RESUMO

A condição de Inglês como Língua Franca tem levado mais e mais alunos de diferentes faixas etárias às salas de aula no mundo todo e muitos desses alunos enfrentam dificuldades no aprendizado de inglês como lingua estrangeira (LE), principalmente a respeito da habilidade oral, o que acaba levando-os a apelar à sua primeira língua durante a aula. Neste trabalho, após a formulação das questões: "Por que alguns alunos insistem em falar Português durante a aula de Inglês?" e "Como eu me sinto quando eu falo Inglês?" a Prática Exploratória (PE) foi usada como ferramenta para coletar dados através do uso de Atividades Pedagógicas Potencialmente Exploráveis (APPEs). A Teoria Fundamentada nos dados foi utilizada para análise dos mesmos. Com este estudo, outros profissionais também poderiam refletir sobre questões similares e trazer outras reflexes que poderiam complementar este estudo.

Palavras-chave: Inglês como Língua Estrangeira, Prática Exploratória, Atividades Pedagógicas Potencialmente Exploráveis, habilidade oral, alunos. 


\section{TABLE OF CONTENTS}

$\begin{array}{ll}\text { Introduction } & 7\end{array}$

Review of the Literature $\quad 9$

$\begin{array}{ll}\text { Methodology } & 16\end{array}$

$\begin{array}{ll}\text { The course, its schedule and more anecdotes } & 17\end{array}$

$\begin{array}{ll}\text { The group } & 17\end{array}$

$\begin{array}{ll}\text { Characteristics of the group } & 18\end{array}$

$\begin{array}{ll}\text { The students } & 19\end{array}$

The first attempt of a puzzle $\quad 23$

$\begin{array}{ll}\text { Picture } 1 & 25\end{array}$

$\begin{array}{ll}\text { Picture } 2 & 26\end{array}$

$\begin{array}{ll}\text { Data discussion } & 28\end{array}$

$\begin{array}{ll}\text { Activity } 1 & 29\end{array}$

Activity 2

Data Analysis $\quad 37$

Final Considerations $\quad 43$

References $\quad 45$ 


\section{INTRODUCTION}

The importance of the English language has been increasing during the past and actual decades and this factor has been pushing more and more learners of different ages into English as a Foreign Language (EFL) classrooms. A few decades ago, it was more usual to find children and teenagers attending this kind of lessons, but nowadays the percentage of young adults and even senior citizens inside an EFL classroom has raised due to different possible reasons: either they are trying to get a raise or a promotion in their jobs or they want to feel more confident to speak when they travel abroad, or some of them, like the elderly learners, think that learning another language will keep them active and this might reduce the risk from suffering a degenerative brain disorder. But once they are enrolled at a course and start taking the lessons and thus progressing to the next proficiency levels, apparently their confidence level seems to get blocked when they need it the most: when they are supposed to speak in class, be it answering questions or making considerations about a topic.

After observing this behavior in some of my adult learners of various ages and occupations who enrolled at a private language course in the south side of Rio de Janeiro, in an intermediate/upper intermediate level group, and having my first contact with Exploratory Practice in the "Especialização em Língua Inglesa" course at PUCRio, I came up with the puzzle: "WHY DO SOME STUDENTS INSIST ON SPEAKING PORTUGUESE DURING AN EFL CLASS?", which aims at trying to understand the factors that might cause this blockage on learners and make them not to speak whenever they are supposed to do it. Thus, one of the methods used to collect and analyze the data was based on the Exploratory Practice (EP) principles as elaborated by Allwright and Hanks (2009, pp. 166-7), who say that EP involves practitioners-teachers and students-working together to understand whatever issue they want to by using normal pedagogic activities as investigative tools.

When I introduced to the students this first puzzle and the Potentially Exploitable Pedagogic Activity (PEPA) used to collect the data during two topic review lessons, they got confused and did not understand the purpose of the exercise. I reformulated the puzzle so they could understand better the whole process of what was going on. The new puzzle, then, was "HOW DO I FEEL WHEN I SPEAK ENGLISH?" 
used in a PEPA where they had to choose the best adjectives that would answer this question while making comparisons. This time, the activity was well succeeded and I could realize that, at some moments, it is necessary to come up with other puzzles so that the information can be produced and the puzzle better understood. The method I used to analyze the data was based on the Grounded Theory principle, as stated by Richards (2003, pp. 16-18), which says that this theory supplies a systematic form of interpreting and analyzing the data through the use of coding procedures, such as tables or charts, in order to identify categories in the data that will later on originate a theory.

This paper is divided into five different sections, after this introduction: 1Review of the Literature, where I will talk about Exploratory Practice and its principles, as well as feelings involved in the learning process; 2- Methodology, where I will explain how I conducted this work; 3- Data Discussion, where I will present my data; 4Data Analysis, where I will analyze the data and 5- Final Considerations. Hopefully, after reading this work, other teachers can find some help to deal with similar issues in their classrooms or even with forthcoming ones that can be dealt with by using the principles of Exploratory Practice. In my case, I was able to realize that students do not communicate in English due to the feelings they have during the learning process, which has made me more aware of the importance of feelings and affect during the acquirement of knowledge. 


\section{REVIEW OF THE LITERATURE}

The process of learning a first language involves different physical and emotional factors that have been extensively studied. Chomsky (1972) apud Singhal (2012) asserted that the mechanism of language acquisition is derived from innate processes, something which has already been in mind since birth. He also believes that knowledge is built by the input of chunks of information that are absorbed by learners and that, since there are stages of development for other parts of the body, language development can also be achieved up to a certain age, being it a completely asocial process.

On the other hand, the acquisition of a second language involves different processes and counts on several approaches, reflecting the multiplicity and complexity of the process, as stated by Van Patten and Rothman (2014) apud Rebuschat (2015). These authors also affirm that the linguistic system in a speaker's brain is abstract, that is, it does not correspond to a set of prescriptive rules and it is derived from different general properties.

Van Patten and Rothman (2014) apud Rebuschat (2015) also affirm that, in order to acquire a second language, the presence of different skills in the learners is necessary, and this factor is embedded in all of the manifestations of communication: interpretation (reading, listening), expression (writing, speaking) and negotiation (conversational interaction, turn taking). Besides that, Rothman and Slabakova (2017) affirm that the process of SLA involves interlanguage development and it is a complex and ongoing work, which can be affected by many variables such as cognition, individuality and social aspects. Due to this diversity of components, it is understandable that there are several different approaches to SLA, which explains some factors that influence linguistic competence and performance in adult non-native language learners.

Besides that, Howatt (1984), apud Allwright and Hanks (2009), pointed that the knowledge of a second language is the result of communicative activity and students must use their communicative skills for the sake of learning the new language. And in agreement with Firth and Wagner (1997) apud Allwright and Hanks (2009), who stated that language is not only the product of one's brain as in a cognitive process, but it is 
also a social circumstance that is acquired and used in interactive ways. Allwright and Hanks (2009) corroborated this statement affirming that language acquisition is seen as an essentially personal process and in order for it to happen it is necessary that the target language is available to the students, being interaction with other language learners fundamental, thus reinforcing the importance of the social factor in the process of the foreign language acquisition.

This social significance of the foreign language acquisition fits into two of the learners' propositions established by Allwright and Hanks (2009, pp. 4-7). One of these propositions asserts that learners are unique individuals, meaning that they should not be considered like just an input box, since each one of them has its own difficulties, struggles and peculiarities. The other proposition states that learners are social beings who develop best in a mutually supportive environment, so communication in general in a favorable environment is fundamental for the learners' knowledge acquisition process. All the propositions will be further analyzed in a subsequent part of this section.

Because students can be considered co-creators of their knowledge and have the same importance as the teacher in the classroom environment, they should be involved in the thinking for understanding. As affirmed by Allwright and Hanks (2009, p. 149) in principles one - "Quality of life for language teachers and learners is the most appropriate central concern for practitioner research in our field" and in principle two "Working primarily to understand the 'quality of life' as it is experienced by language learners and teachers, is more important than, and logically prior to, seeking in any way to improve it." Sharing this process of working for understanding classroom life can be a way of enhancing the quality of life in that environment. These principles led me to conduct my research, because students were part of the process and we worked together to understand and better handle the puzzle that emerged in the classroom.

Thus, because of the collegial work between practitioners, a research that involves Exploratory Practice can be considered practitioner research and included in a participatory paradigm. According to Allwright and Hanks (2009, p. 172), EP may involve two conceptually different processes: taking action for understanding (EP itself) and taking action for change (action research). Although EP prioritizes understanding over change, the understandings generated through EP are capable of handling the 
process of change, since learners and teachers as well as school staff - such as management, coordinators, etc. - work together to comprehend a specific issue.

Exploratory Practice focuses on working for understanding rather than on problem solving, uniting pedagogy and research through language learning activities to conduct investigations, as stated by Hanks (2017, pp. 27-28). Thus, EP brings together learners and teachers to try to understand a situation that might be interfering in their learning process and in their lives by the formulation of puzzles. According to Hanks (2017, p. 31): "being puzzled enables us to reveal our developing understandings to ourselves and it allows a greater depth."

However, the solution of a puzzle is not permanent due to the dynamic environment of a classroom: we have different people with different feelings, thoughts and impressions involved. Each individual in that environment can be considered unique, and people are constantly changing, as stated by Tudor (2001) apud Allwright and Hanks (2009, p.1), who says that learners bring to the classroom their individualities and personalities as they are at a certain moment in time. This factor influences their interaction with teachers and among themselves, and besides that, this interaction best occurs when a good classroom environment is established in a spirit of mutual support and development. This way, students feel more comfortable and confident enough to absorb and use the input transmitted in class, reinforcing the importance of affect and feelings in the second language acquisition process. Allwright and Hanks (2009, p.7) corroborate this idea through the Five Learners' Propositions, which are:

- Learners are unique individuals who learn and develop best in their own particular ways

- Learners are social beings who learn and develop best in a mutual supportive environment

- Learners are capable of taking learning seriously

- Learners are capable of independent decision-making

- Learners are capable of developing as practitioners of learning

These propositions only reinforce the idea that students are and must be faced as "one and only" persons in a classroom environment, and teachers should be aware of that when planning their lessons by trying to individualize as much as possible the way 
they conduct a class, and also when expecting an output from the learners during classes, by not putting too much pressure on learners and reinforcing the positive aspects whenever any progress is made.

As previously mentioned, affect and feelings are other aspects that should be taken into consideration when it comes to L2 learning and teaching. As stated by Arnold (2009, p. 147), this relationship between affect and learning is essential for language learning because learners feel more vulnerable when they do not master the language yet. This is corroborated by López \& Aguilar (2013, p. 121), who say that the process of learning a language is full of negative and positive emotions, and an appropriate management of students' emotions is necessary in order to help them make these feelings work for them and not against them. So, language teachers must be aware of the influence of these factors during students' learning process. They also should try to keep a positive learning environment, through promoting group cohesion and establishing a good teacher-student relationship. Macintyre et al. (1998) apud Arnold (2009, p.147) suggest that learning programs should create in learners the willingness to communicate, and affect plays an important role in this part, which is confirmed by Dörnyei (2014, p. 519), who states that motivation constantly interacts with cognitive and emotional issues, becoming components of the learning process.

Since learners should be considered unique individuals in the classroom, their emotions are the first factor to be taken into consideration when planning a foreign language lesson: Pekrun et al (2002) apud López \& Aguilar (2013, p. 113) suggested that raising awareness on learners about their feelings could be a tool teachers use to help learners overcome negative emotions and foster positive ones. The PEPAs used in order to collect data for this work somehow accomplished this mission, as it will be further explained in the following sections of this paper.

Pekrun et al. (2002) apud López \& Aguilar (2013, p.120) affirm that both positive and negative emotions have an impact on learners' motivation, since they can activate or deactivate the willingness to learn. If a pupil had had a previous pleasant learning experience, he or she will carry this positive impression with him/her throughout his/her life. On the other hand, if the learner had not had an enjoyable learning experience before, he/she will bring along these negative impressions with him/her for a long time, which can possibly interfere in his/her future learning process. 
MacIntyre \& Gregersen (2012, p. 193) corroborate this idea, stating that positive emotions tend to broaden one's perspective, opening the individual to absorb the language, whereas negative emotions promote the opposite effect, reducing the focus and restricting the range of potential language input. Thus, it is necessary for the teachers to bear in mind that affect and feelings play an important role in the second/foreign language acquisition process, and this fact should be remembered when a lesson is planned, for instance, adjusting the language used to the students' proficiency level, making constructive comments in the corrections of tests and tasks, and so on and so forth.

When it comes to negative feelings involved in language learning, anxiety is the most mentioned in many works that refer to this topic. MacIntyre \& Gregersen (2012, p.195) state that this anxiety brings along with it other associated feelings, such as dread, nervousness, typically preceding avoidance or escape. They appear when people feel threatened, as a means of self-protection, a situation that is very common to happen during a speaking lesson or at any time students have to utter in the foreign language. This information is corroborated by Simsek \& Dörnyei (2017, p. 53), who affirm that language anxiety has signs, such as freezing up during oral production and displaying physiological symptoms, like blushing, shaking, sweating and avoiding eye contact, amongst others. Simsek \& Dörnyei (2017, p. 59) also state that this weakening, fear-like emotion not only reduces the productivity and efficiency of students' performance, but also causes a great feeling of inquietude in them.

Regarding positive emotions involved in the process of language learning, Fredrickson (2006) apud MacIntyre \& Gregersen (2012, p. 197) claims that these sensations tend to enhance people's attention and thinking, leading to exploration of new experiences and learning, also promoting resilience by triggering positive reactions to stressful events. Bolitho et al. (2003) apud MacIntyre \& Gregersen (2012, p. 198) reiterate this information affirming that the affective engagement in use stimulates a fuller use of the resources of the brain, because positive attitudes raise people's selfesteem, which helps to promote neural paths between many areas of the brain and then reaching the multi- dimensional figure needed for absorbing the language.

In relation to motivation, as stated by Dörnyei (2014, p. 519), it can be considered as both an internal and an external factor to the learner, being propelled by 
curiosity or the social context in which the student is inserted, for example, and determining the direction and magnitude of his/her behavior, and the same author ( $\mathrm{p}$. 520) affirms that sometimes the motivation to learn a language comes from successful learning experiences and does not depend on internal nor external factors. This information is reiterated by Pekrun et al. (2002) and Meyer \& Turner (2006) apud López \& Aguilar (2013, p. 112), who say that emotions and feelings felt by sudents are important to understand the teaching and learning processes, as well as students' motivation. Dörnyei (2014, p. 520) also affirms that a learner's success in the mastering of a foreign language is directly related to their level of motivation. In addition to this, Fredrickson (2003) apud MacIntyre \& Gregersen (2012, p. 197) states that certain positive emotions, such as pride, joy, contentment and love share the ability to enhance people's temporary thought-action repertoires and build their social and physiological resources.

Afterthought, Fredrickson (2001) apud MacIntyre \& Gregersen (2012, pp. 2078) mentions that there are some examples of positive feelings and tendencies they predict, such as joy, that creates an urge to expand boundaries and creativity; interest, that generates an urge to explore, absorb new information and develop self; and contentment, that allows a person to keep positive events and integrate them into one's point of view of the world. Thus, as stated by López \& Aguilar (2013, pp.120-1), "motivation in language learning cannot be developed in a vacuum: certain conditions need to be present before motivation can be initiated."

As discussed in this literature review, it is possible to affirm that emotions are an important part in the language learning process, or as stated by López \& Aguilar (2013, p. 112), emotional experiences play a significant role in the reasons students decide to study a foreign language or to keep up with a task, and it is important for language teachers to be aware of this so that they can adjust their approach to learners, helping to reduce the negative impact emotions can have on the pupils and enhancing the feelings that promote their motivation to learn. 


\section{METHODOLOGY}

My introduction to the Exploratory Practice universe and everything that is involved with it, PEPAs included, was during the Especialização em Língua Inglesa 2016.2 course at PUC-RIO, with professors Maria Isabel Cunha and Inés Miller. Along the module, they explained to us the importance of working for understanding, as well as the other principles, such as working primarily to understand the quality of life as it is experienced by language teachers and learners, the need to be involved in the work for understanding, the need of bringing people together, the necessity of the work to be conducted in a spirit of mutual development and working for understanding as an activity continuously in progress, as stated by Allwright and Hanks (2009).

The professors also made clear that, in order to have a better comprehension of an instigating issue in the classroom at that moment, it is necessary to come up with a puzzle. This way it would be easier to investigate the reason for that issue using PEPAs as a tool to conduct the research. So, they proposed me and my classmates to think of a puzzle and try to understand it better with the use of PEPAs. The understandings were going to be shown at the EP event that was held some months later at PUC-RIO and this work has turned into this monograph.

After being invited to think of a puzzle, the first thing that came to my mind was: "but there are so many things in my groups that puzzle me"... Right after that, I thought about this specific intermediate/upper intermediate adult group with such different goals yet the same difficulties... The students kept on speaking Portuguese during class, even though their proficiency level was good enough to allow them to carry a conversation in English. So, I formulated the puzzle "WHY DO SOME STUDENTS INSIST ON SPEAKING PORTUGUESE DURING AN EFL CLASS?” which was the first one developed, and I thought about using a revision class on adjectives to formulate the PEPA so that I could understand that situation better. Further information about this group and the institution in which the classes were held will be given in the next pages. 


\section{THE COURSE, ITS SCHEDULES AND ANECDOTES}

The language course is located in two of the main neighborhoods in the south side of the city of Rio de Janeiro (Leblon and São Conrado). Iit has been working for over 20 years and the main public who attended the classes has changed throughout the decades: nowadays most of the enrolled students are young adults and elder ones. There are still a few groups of adolescents enrolled, but not as many as there used to be in the "golden age" of the course's history, perhaps due to the increasing change of the educational system, which has been prioritizing bilingual regular schools lately.

The classes of this particular group that gave origin to my puzzle were held in 2 semesters, with a 14-day break in July, and happened twice a week - on Mondays and Wednesdays, during lunch time - from 12:30 PM to 1:45 PM in the Leblon branch. A textbook was adopted - Top Notch 2, second edition, by Saslow and Ascher (2011) which follows a communicative approach, aligned with the course methodology. However, it was not used in every class because the group would prefer video or conversation activities.

\section{The Group}

As previously mentioned in the previous section, most of the students who enroll in the groups are adults and this one is not different: an intermediate/upper intermediate adult group formed by six ladies with ages varying between thirty-nine and seventy years old and one twenty-eight year-old gentleman. The age difference did not represent a big problem during the lessons, nor did the difference of proficiency level, but the main issue was the different goals each student had regarding learning the language and the different views they had of classroom activities.

The male and the younger female students (two of them who still work) were more focused on improving their English and moving forward in order to get better job positions or taking courses abroad be them an MBA or just an extension course. They would not show any resistance regarding the use of the textbook or the accomplishment 
of any task requested them, nor were they reluctant to speak spontaneously or when asked any question.

The older ladies had different goals: either they wanted to learn and improve their skills in the language for the purpose of travelling (two of them have grandchildren who live abroad: one living in Australia and the other one in Switzerland, or they just wanted to find an activity to keep themselves busy in their spare time that also works as a "brain exercise". Since they are retired and for this reason, they were somehow resistant about the use of the textbook, taking tests, doing homework or other exercises during classes and they did not produce verbally in English in a spontaneous way sometimes they did not speak even when required to do so.

In spite of the age, goals and proficiency differences, the students got along with each other very well, being supportive and friendly. Further details about them will be explained in the next pages.

\section{Characteristics of the group:}

- 7 students (6 females and 1 male)

- Ages: between 28 and 70 years old

- Proficiency level: intermediate and upper-intermediate

- Goals:

-better job positions and studying abroad (younger students); -travelling, pastime, "brain exercise" (older students)

- Lesson/activity preferences:

-keen on using the textbook and doing homework or other tasks in general (younger students);

-not keen on using the textbook nor doing homework and tasks in general (older students) 


\title{
The students
}

(The real names of the students have been changed).

\begin{abstract}
Alice
Alice was a sweet, easygoing lady in her seventies who loved travelling and was a dedicated mother and grandmother. This latter description might already give a clue about the frequency she would attend classes: in one occasion she had been absent for almost three months in a row and after the administration staff and the coordinator had gotten in touch with her, they had found out that one of her sons had had a terrible accident during a trip and she had to take care of her grandchildren whereas he and his wife were at the hospital so that he could go through some surgeries. After he was released from hospital, she had decided to go to her beach house and stay for a whole month there to unwind and relax a little. After that she had to take care of her other grandchildren because her other son had decided to take a trip with his wife as an anniversary celebration. Well, needless to say that after all these events she returned to classes a little demotivated and lost, thus she would not cooperate with the accomplishment of tasks and homework nor would she speak very frequently because she was not feeling confident enough to do so, even though her peers would encourage her and cheer her up. She quit the course before the end of school year.
\end{abstract}




\begin{abstract}
Alba Maria
Alba Maria had studied English during her school years in a traditional and wellrespected catholic school in the south side of Rio de Janeiro, so she had good acquaintance of grammar and the language in general. She was in her mid to late sixties, was retired and had children and grandchildren, of whom she would take care whenever required by her children, which did not occur very often since they live outside the state of Rio de Janeiro. So, she hardly ever missed a class and was very cooperative regarding doing homework, tasks in the classroom, using the textbook and reading activities, although she allegedly hated listening activities "because I cannot understand anything they say". Other than this, she also felt extremely uncomfortable whenever she had to carry out a conversation or answer questions in English because she stated that she would forget many words, which made her feel really frustrated. These factors led her to finish the sentence she had previously started in English in Portuguese and due to this, she would not put much effort on speaking English whenever she had to do so.
\end{abstract}

\title{
Erica
}

Erica was the last one to join the group: she was seventy-three years old (the oldest of the ladies), had two kids and one of them lived in Australia, where she had previously been to. But once she was there, her daughter would translate everything for her, acting like a real interpreter. She was very sweet and kind, never missed a class and was very receptive to any activity proposed in class, like dictations or the use of the textbook. She would do her homework, write compositions- which she did very welland would study at home and bring her doubts to class. But whenever it was her turn to speak I could notice fear on her face and gestures: sometimes she would even shake! Her peers were very supportive and cheered her up, encouraging her to at least try to speak, which sometimes she did but many times she did not do so. In addition to that, whenever she was trying to speak and felt like she could not remember a word, she would replace that word and the rest of the sentence for Portuguese, saying "eu vou falar Português porque é mais rápido, tá?”(“I am going to speak Portuguese because it is faster this way, ok?"). 


\section{Hannah}

Hannah could be included in the "tourists" category of the group, not only because she travelled a lot (one of her daughters lives in Switzerland), but also due to the fact that she missed a lot of classes, sometimes being absent for two or three months in a row, be it for personal matters or health problems or...trips! Owner of a strong personality, she was not afraid of speaking up for what she and her peers wanted, although she did this in Portuguese. The moment she had to speak English her strong personality made way for a shy, not so confident woman. Although she missed many classes, she would cooperate with the accomplishment of tasks, doing the homework and using the textbook, but she would also state that, in spite of being enrolled at that course for over two years and often travelling abroad, she did not feel confident enough whenever she had to utter spontaneously in English. She also admitted that her absences were interfering a lot in her learning process, but she did try to catch up with the topics as soon as she returned to classes and when she was starting to get into the rhythm again, she would "disappear".

\section{Marta}

Marta is on her fifties and still works (she and her husband run a consultancy business), thus she has a lot of business and lunch meetings with business partners and she loves hosting dinners in her house. Owner of an outgoing and persistent personality, even with her busy schedule, she would hardly ever miss a class and even if she did, she would ask about the topics that she had missed and would study them at home, bringing her doubts to the following class. She was not afraid of speaking even knowing that she made some mistakes and she would also encourage her classmates to speak when they did not feel confident enough to do so. 


\section{Nair}

Nair is the youngest of the ladies (she is thirty-nine years old), has two kids and runs a gym. Her husband is a jet pilot and because of that she gets free tickets (or ones with great discounts) and travels a lot, be it around the country or abroad. But even with this "travelling" lifestyle, her proficiency in the language is not that high and she does not feel intimidated whenever she has to speak English. Other than that, she alleged that she is studying in order to improve what she already knows and because she also plans to take a course in her area abroad when her kids get a little older. She is very communicative and supportive and would aid her peers any time they asked for assistance. Besides that, she was very cooperative regarding the realization of tasks, the use of the textbook and doing homework.

\section{Saulo}

The only man in the group, Saulo is twenty-nine years old, has a major in Economy and works for a company that negotiates stocks. At the present moment he is taking an MBA degree at PUC-Rio and he intends to apply for getting a $\mathrm{Ph}$. D. degree abroad, therefore he wants to improve his English so that he gets a brilliant score on his proficiency test. He did not miss many classes unless he had meetings at work or exams at the university, but when he did, he would catch up with the topics right away. Due to his concern about the proficiency test, he would study the subjects, but he did not write compositions when he was supposed to and he would practice the skills at home and ask for suggestions of books to study more whenever he had some spare time. In the beginning, speaking was a big issue for him because other than being extremely shy and feeling a bit intimidated in a class composed only by women, he used to speak with a stutter. After talking to him and suggesting him to search for a speech therapist, he actually did and his progress could be seen month after month. In the present moment he does not stutter anymore and his confidence seems to have skyrocketed, and he even encourages his classmates to speak when they do not feel so secure to do so, even though he still is very timid. 


\section{THE FIRST ATTEMPT OF A PUZZLE}

When I met this group on the week right after the formulation of the puzzle WHY DO SOME STUDENTS INSIST ON SPEAKING PORTUGUESE DURING AN EFL CLASS?, I wrote it on the board, gave each one of them a sheet of paper folded in two and in the first half they could write one or more adjectives that came to their minds representing the way they felt when they spoke English. On the other half, they could justify why they chose that or those adjective(s).

At first, the students were having a hard time to understand the purpose of the exercise as well as what should be done: they could not figure out how a review exercise on adjectives would be able to make me understand why they spoke Portuguese during class. So, I reformulated the puzzle in order to make it easier for them to do the task and for me to understand the situation, since they could not comprehend the initial puzzle and thus do the exercise I had requested them to do. This situation might have happened because the learners did not visualize themselves asking the question "Why do some students insist on speaking Portuguese during an EFL class?", since they did not recognize themselves as "some students". So, I reformulated the puzzle: "HOW DO I FEEL WHEN I SPEAK ENGLISH?' and this time it was easier for them to understand the exercise because they could actually visualize themselves asking this question. They had to choose adjectives from a list to form the correspondent comparatives in pre-suggested sentences that would represent the way they felt whenever they spoke English. They also had to justify why they used those specific adjectives.

This first experience of coming up with a puzzle and then having to elaborate a new one because the students had not understood the purpose of the activity made me reflect upon the awareness learners have of their own learning process. I could understand that the initial puzzle was a questioning that I had to myself, adapted and turned into their puzzle for the grammar activity. It was not possible to say that it was a questioning they actually had and that they were puzzled about their learning process. The puzzle I wanted to understand more of was mine and the way I was asking the question in the exercise ("Why do some students insist on speaking Portuguese during an EFL class?") showed that. As a matter of fact, I could notice that this issue fit into 
Exploratory Practice's principles three, four and five as stated by Allwright and Hanks (2009, p.151), because I was trying to investigate a question that was related to the students' feelings and in which ways that bothered me, highlighting the importance of the involvement of everybody in the work for understanding (Principle 3). Also, this ended up raising awareness about the importance of paying attention to the students' feelings and concerns on me, which resulted in the students' satisfaction towards the relationship teacher-student, strengthening the connection between me and them (Principle 4). Thus, this made me realize that the work must be conducted in a spirit of mutual development (Principle 5), because, in this way, students can recognize the importance they have in their own learning process.

Besides that, still according to Allwright and Hanks (2009, p. 260), EP creates channels between learners and teachers, and the puzzle reformulation clearly brought up a means of communication between me and my group of students. It was due to their doubt that I had to rearrange the whole activity so that they could understand it better. So I can say that, after being aware of this important communication link, I have learned from my group of learners that sometimes students can be teachers too and there is nothing wrong with this.

After giving their answers, the group elaborated two posters that later were presented as the final work for the EP module at PUC-RIO's "Especialização em Língua Inglesa" course. These posters were also exhibited during the EP event that took place at PUC-RIO, in November 2017 and can be seen on the next pages. 
PICTURE 1 -POSTER CREATED BY THE STUDENTS

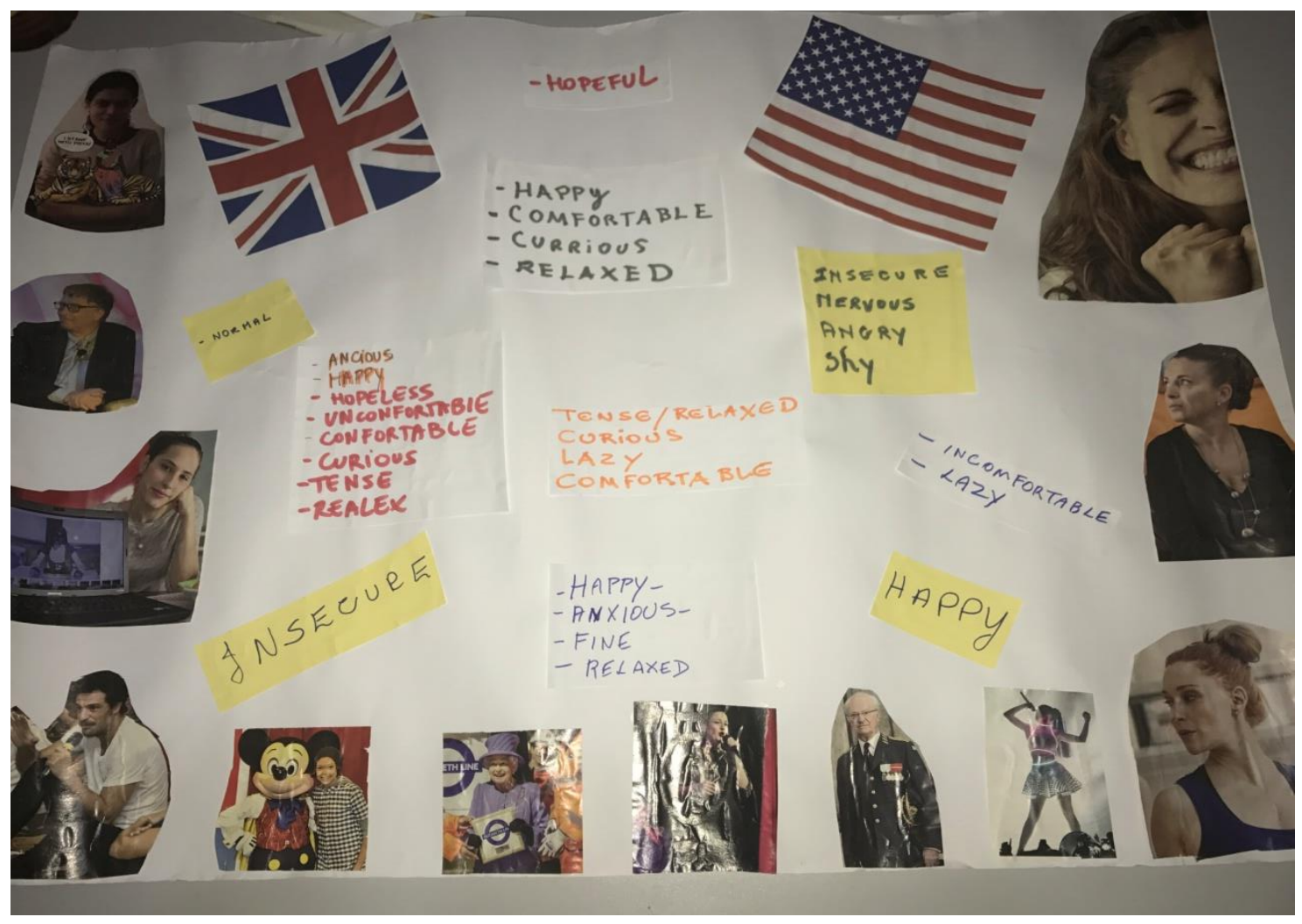


PICTURE 2-POSTER CREATED BY STUDENTS

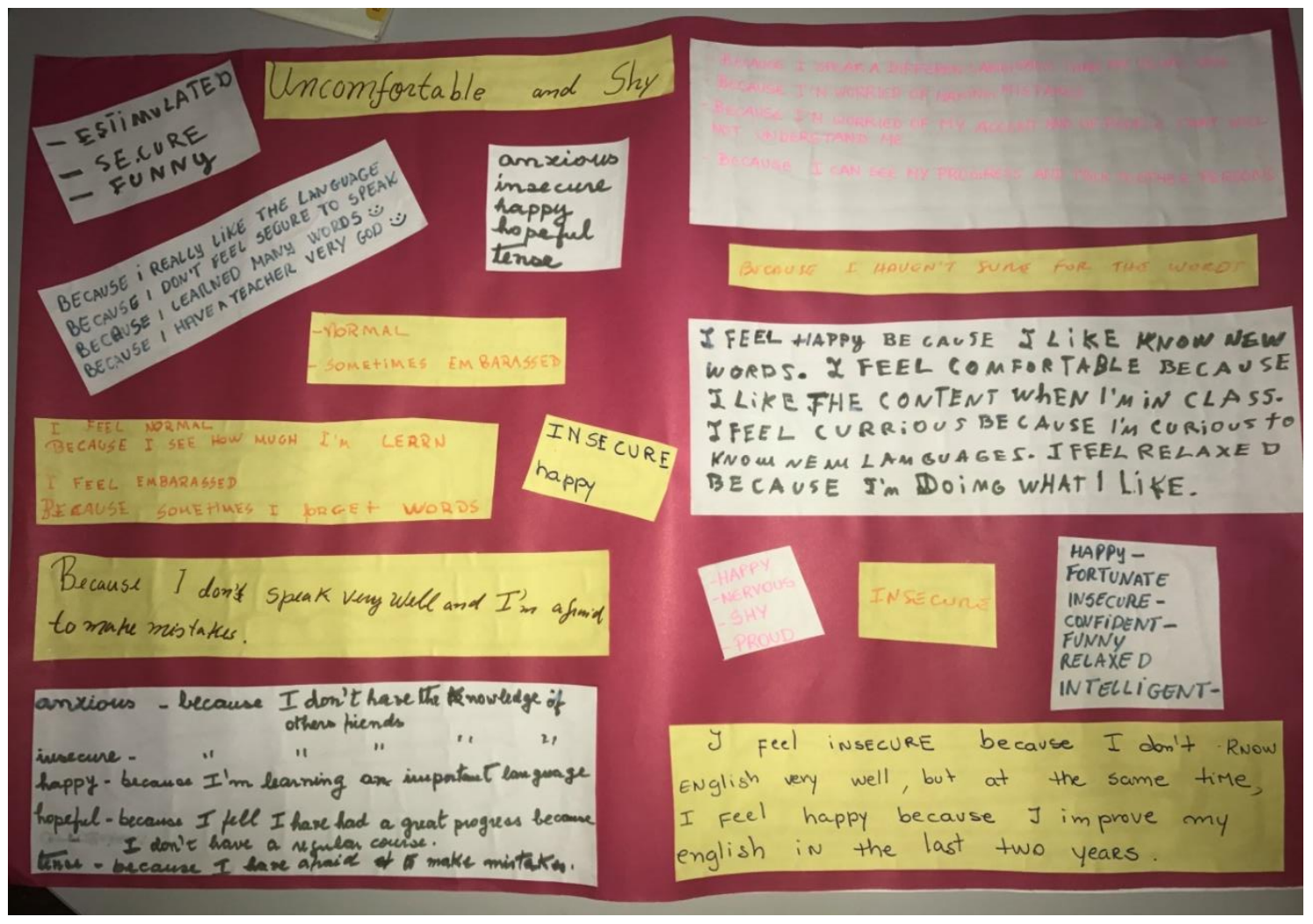

For reasons of illegibility, the contents of this poster will be listed on the next page, from left to right; 
- Estimulated, secure, funny

- Uncomfortable and shy

- Because I speak a different language than my usual one; because I'm worried of making mistakes; because I'm worried of my accent and of people that will not understand me; because I can see my progress and talk to other persons

- Because I really like the language, because I don't feel secure to speak, because I learned many words, because I have a teacher very god.

- Anxious, insecure, happy, hopeful, tense

- Because I haven’t sure for the words

- Normal; sometimes embarrassed

- I feel normal because I see how much I'm learn, I feel embarrassed because sometimes I forget words

- Insecure, happy

- I feel happy because I like know new words. I feel comfortable because I like the content when I'm in class. I feel curious because I'm curious to know new languages. I feel relaxed because I'm doing what I like.

- Because I don't speak very well and I'm afraid to make mistakes.

- Happy, nervous, shy, proud

- Insecure

- Happy, fortunate, insecure, confident, funny, relaxed, intelligent

- Anxious- because I don't have the knowledge of other friends; insecurebecause I don't have the knowledge of other friends; happy- because I'm learning an important language; hopeful- because I feel I have had a great progress because I don't have a regular course; tense- because have afraid of make mistakes

- I feel insecure because I don't know English very well, but at the same time I feel happy because I improve my English in the last two years. 


\section{DATA DISCUSSION}

This qualitative research was done using Potentially Exploitable Pedagogic Activities as a means of collecting data, using the students' answers and thoughts as tools to conduct this work and Grounded theory to assist me to organize the data in tables and categories in systematized ways, so that the data analysis would be easier to be accomplished later on.

According to Richards (2003, pp. 16-18), Grounded theory supplies a systematic form of interpreting and analyzing the data through the use of coding procedures such as tables or charts in order to identify categories in the data that will later on originate a theory. The categories shown in the tables are divided into positive, neutral or negative feelings according to the adjectives used by the students in the activity, so that it would be easier for me to analyze the data. Some students used the adjectives angry, fortunate, hopeless, lazy, secure and stimulated, too, but they did not write any correspondent justification for electing these words, thus they were left out of the tables. The answers and justifications given by the students in both posters of this first activity are shown in the tables below.

After the accomplishment of the first PEPA, which was well-received by the students because they felt involved with it, another activity was done during a topic review lesson on the use of adjectives and comparatives. An exercise sheet was distributed to each one of the students and they had to complete six sentences, choosing the best adjectives to form the comparatives according to their personal opinion regarding English and Portuguese, later justifying their choice. Their answers were also organized in tables in order to facilitate the analysis of the data and the exercise is further shown in the coming pages. 


\section{Activity 1}

As I organized the results in the table under the perspective of the students' feelings, I was able to observe a more complete picture of the diversity of the responses given by the students, based on their emotional experiences.

\section{Table 1- Chosen Adjectives and Students' Justifications for their Choices}

In this table, the adjectives chosen by the students are organized in the category of positive feelings, since the words themselves carry with them a positive connotation and the students' justifications were all related to good feelings and impressions they had.

\begin{tabular}{|l|l|}
\hline POSITIVE FEELINGS & Jecause... \\
\hline Comfortable & I like the content when I'm in class \\
\hline Confident & I learned many words \\
\hline Fortunate & I really like the language \\
\hline Fun & I have a teacher very god \\
\hline Happy & $\begin{array}{l}\text { I really like the language } \\
\text { I improve my English in the last two years I'm learning an } \\
\text { important language } \\
\text { I like know new words } \\
\text { I speak a different language than my usual one }\end{array}$ \\
\hline Hopeful & $\begin{array}{l}\text { I feel I've had a great progress } \\
\text { I don't have a regular course }\end{array}$ \\
\hline Intelligent & I learned many words \\
\hline Proud & I can see my progress and talk to other persons \\
\hline
\end{tabular}




\section{Table 2- Chosen Adjectives and Students' Justifications for their Choices}

In this table we can see the adjectives categorized in neutral feelings, because the words that the students chose do not carry with them any positive nor negative connotation, as well as the justifications. It is possible to notice the different sensations students have when learning English and it suggests that students are curious about and engaged on learning the language.

\begin{tabular}{|l|l|}
\hline NEUTRAL FEELINGS & Because... \\
\hline Curious & I'm curious to know new languages \\
\hline Normal & I see how much I'm learn \\
\hline Relaxed & $\begin{array}{l}\text { I'm doing what I like } \\
\text { I have a teacher very god }\end{array}$ \\
\hline
\end{tabular}

\section{Table 3- Chosen Adjectives and Students' Justifications for their Choices}

In this table the adjectives chosen by the students have a negative connotation, as well as the justifications they gave to have chosen those words. With these results, it is possible to notice that most of the students' justifications suggest fear or worry to make mistakes, suggesting an issue of low self-esteem and/or lack of confidence.

\begin{tabular}{|l|l|}
\hline \multicolumn{1}{|c|}{$\begin{array}{c}\text { NEGATIVE } \\
\text { FEELINGS }\end{array}$} & Because... \\
\hline Anxious & I don't have the knowledge of other friends \\
\hline Embarrassed & sometimes I forget words \\
\hline Insecure & $\begin{array}{l}\text { I don't feel secure to speak } \\
\text { I don't know English very well } \\
\text { I haven't sure of the words } \\
\text { I don't have the knowledge of other friends }\end{array}$ \\
\hline Nervous & I'm worried of making mistakes \\
\hline Shy & $\begin{array}{l}\text { I'm worried of my accent and of people that will not } \\
\text { understand me } \\
\text { I don't speak very well and I'm afraid to make mistakes }\end{array}$ \\
\hline Tense & I have afraid to make mistakes \\
\hline Uncomfortable & I don't speak very well and I'm afraid to make mistakes \\
\hline
\end{tabular}




\section{ACTIVITY 2}

As previously explained, in this activity students had to choose the adjectives to later on make the comparisons according to their feelings regarding speaking English, the Portuguese language, comparisons between the two languages and how they felt whenever they had to communicate. The exercise sheet is reproduced below:

CHOOSE THE ADJECTIVE TO FORM A COMPARATIVE AND JUSTIFY YOUR ANSWER:

1) English is (easy/difficult/hard/good/bad) Portuguese, because

2) When I speak English, I feel (happy/sad/intelligent/comfortable/uncomfortable/shy/confident) when I speak Portuguese, because

3) English classes are (fun/boring/interesting/difficult/easy) Portuguese classes, because

4) I feel (smart/confident/intelligent/shy/insecure) when I started studying English, because

5)English words are (easy/practical/interesting/difficult/long/big) Portuguese words, because

6) Studying English is (easy/difficult/boring/interesting/important) studying Portuguese, because

The students' answers were also organized in tables and under categories of feelings according to the contents of their responses in order to facilitate the reading of the data for a future analysis. 


\section{Activity 2}

\section{Table 4: The Comparatives and their Justifications}

In this table, the comparatives formed by the students are gathered into the category of positive feelings because these words carry with them a positive connotation as well as the students' justifications and it made the subsequent analysis of the data easier for the analysis. The results were organized in this perspective to present a more complete picture of the diversity of the responses given by the students, based on their emotional experiences.

\begin{tabular}{|c|c|}
\hline POSITIVE FEELINGS & JUSTIFICATIONS \\
\hline As easy as & I like learning English \\
\hline As important as & $\begin{array}{l}\text { it is better for my future } \\
\text { it is good to be bilingual }\end{array}$ \\
\hline As interesting as & I like studying both languages \\
\hline Easier than & $\begin{array}{l}\text { English does not have a lot of verbs } \\
\text { English has less verb tenses } \\
\text { Portuguese grammar is very difficult } \\
\text { studying Portuguese is boring but studying English is fun }\end{array}$ \\
\hline Happier than & $\begin{array}{l}\text { I want to learn English } \\
\text { it is another language }\end{array}$ \\
\hline Less insecure than & I need to study more English \\
\hline More confident than & $\begin{array}{l}\text { I always learn new topics } \\
\text { I think we need to study all the time to develop } \\
\text { now I have a larger vocabulary }\end{array}$ \\
\hline More fun than & $\begin{array}{l}\text { there is more conversation and more interaction } \\
\text { Portuguese classes are boring }\end{array}$ \\
\hline More important than & $\begin{array}{l}\text { English is a universal language } \\
\text { some "guys" in my country speak English } \\
\text { English is the second language of the world } \\
\text { you can communicate with the world } \\
\text { it is another language and it is interesting }\end{array}$ \\
\hline More interesting than & $\begin{array}{l}\text { I have an opportunity to learn another language and I love } \\
\text { it } \\
\text { it opened the world for me } \\
\text { I try to talk } \\
\text { I am learning a new language and I like it } \\
\text { I learn another language } \\
\text { it is different } \\
\text { I already know words in Portuguese }\end{array}$ \\
\hline Smarter than & $\begin{array}{l}\text { I want to visit other countries and talk to the foreigners } \\
\text { I already know Portuguese and it is boring I am learning a } \\
\text { new language }\end{array}$ \\
\hline
\end{tabular}




\section{Table 5: The Comparatives and their Justifications}

In this table, the comparatives chosen by the students bring along with them a more neutral connotation, that is, they describe their feelings towards more technical issues of the language, so they were gathered into the category of neutral feelings. The results were organized in this perspective to show that students recognize that there are differences between English and Portuguese but this factor does not represent a hindrance to their knowledge acquirement of the English language.

\begin{tabular}{|l|l|}
\hline NEUTRAL FEELINGS & \multicolumn{1}{c|}{ JUSTIFICATIONS } \\
\hline Longer than & English words are more difficult to understand \\
\hline More practical than & $\begin{array}{l}\text { it is more objective } \\
\text { the usual words that we use every day are short and easy } \\
\text { to learn } \\
\text { it brings a lot of opportunities to communicate with the } \\
\text { world }\end{array}$ \\
\hline
\end{tabular}

\section{Table 6: The Comparatives and their Justifications}

In this table, the comparatives and the justifications used by the students carry with them a negative connotation and for this reason they were gathered into the category of negative feelings. The results were organized in this perspective to demonstrate some struggles the students face when learning English and some difficulties they have with the language, particularly when compared to Portuguese.

\begin{tabular}{|l|l|}
\hline NEGATIVE FEELINGS & Because... \\
\hline As difficult as & Jhere are a lot of details in the grammar \\
\hline Less comfortable than & I have a lot of difficulties in pronunciation \\
\hline More difficult than & $\begin{array}{l}\text { it is not my native language and the structure is different } \\
\text { Portuguese is my first language } \\
\text { the words in English are difficult and have a lot of } \\
\text { meanings } \\
\text { there are many consonants in English } \\
\text { I have difficulty to understand and I have many doubts } \\
\text { one word in English can have many meanings } \\
\text { there are many meanings for the same word } \\
\text { I was born in Brazil } \\
\text { I was born here }\end{array}$ \\
\hline More insecure than & $\begin{array}{l}\text { I do not speak English very well } \\
\text { I forget a lot of things } \\
\text { for me English is difficult }\end{array}$ \\
\hline
\end{tabular}




\begin{tabular}{|l|l|}
\hline & I do not know the language \\
\hline More uncomfortable than & $\begin{array}{l}\text { I speak Portuguese since I was young } \\
\text { I do not speak English very well } \\
\text { I do not try to talk to some people } \\
\text { I do not know English very well } \\
\text { it is not my language }\end{array}$ \\
\hline Sadder than & I cannot speak English very well after studying it for years \\
\hline Shier than & $\begin{array}{l}\text { I do not speak well } \\
\text { I am worried of making mistakes } \\
\text { I am afraid of forgetting the words }\end{array}$ \\
\hline
\end{tabular}

\section{Table 7: Some Similar Justifications and Topics}

In this table, the students' justifications were gathered into topics that were found to have something in common with each other: some of them mentioned the importance of the language regarding communication, others made comparisons between English and Portuguese, others mentioned the importance of English to their lives and some other made reference to their language learning process.

\begin{tabular}{|c|c|}
\hline TOPICS & JUSTIFICATIONS \\
\hline Communication & $\begin{array}{l}\text { I want to visit other countries and talk to foreigners } \\
\text { it opened the world for me } \\
\text { it brings a lot of opportunities to communicate with the } \\
\text { world } \\
\text { you can communicate with the world } \\
\text { some "guys" in my country speak English }\end{array}$ \\
\hline $\begin{array}{l}\text { Comparisons between L1 } \\
\text { and English (as languages } \\
\text { andr geographic } \\
\text { differences) }\end{array}$ & $\begin{array}{l}\text { Portuguese grammar is very difficult } \\
\text { studying Portuguese is boring but studying English is fun } \\
\text { I already know Portuguese and it is boring } \\
\text { Portuguese classes are boring } \\
\text { Portuguese is my first language } \\
\text { I was born in Brazil } \\
\text { I was born here } \\
\text { I speak Portuguese since I was young } \\
\text { I do not speak English well } \\
\text { it is not my native language } \\
\text { I do not know English well } \\
\text { it is not my language } \\
\text { I already know words in Portuguese } \\
\text { it is different } \\
\text { for me English is difficult } \\
\text { I do not know the language }\end{array}$ \\
\hline Importance of English & $\begin{array}{l}\text { English is a universal language } \\
\text { English is the second language of the world } \\
\text { it is good to be bilingual }\end{array}$ \\
\hline
\end{tabular}




\begin{tabular}{|c|c|}
\hline Language learning process & $\begin{array}{l}\text { now I have a larger vocabulary } \\
\text { I always learn new topics } \\
\text { I like learning English } \\
\text { I have an opportunity to learn another language and I love } \\
\text { it } \\
\text { I am learning a new language } \\
\text { I learn another language } \\
\text { I want to learn English }\end{array}$ \\
\hline
\end{tabular}




\section{DATA ANALYSIS}

\section{ACTIVITY 1}

Table 1 shows adjectives associated with positive feelings students have when they speak English and their correspondent justifications. The most mentioned adjective was "happy" and the students' reasons for choosing this word were somehow similar in their contents, because they all mention the importance of learning a different language and their enjoyment towards English. But even feeling satisfied they apparently do not think they are able to communicate verbally in the language; an issue that is repeated in the election of other adjectives ("comfortable", "confident", "fortunate", "fun", "hopeful", "intelligent", "proud") and their correspondent justifications, when they mentioned their satisfaction about learning a new language and the major role this fact plays in their lives, which might suggest a bit of lack of self- confidence from their part.

In conclusion, apparently the students are satisfied with the course methodology, the contents of the lessons and the teacher. They also recognize the major role that the language plays in their lives and the problem seems to be their lack of confidence that results on shyness and discomfort whenever they are required to speak in English.

Analyzing the data in Table 2 we can see adjectives that were considered neutral and were arranged this way because in this category the comparatives and justifications were more related to technical issues of the language, such as grammar and vocabulary, and comparisons between English and Portuguese. These factors do not seem to interfere with their learning process nor with the moment when they have to communicate in English.

The adjectives present in the table are "curious", "normal" and "relaxed" and the justifications associated to them mention the students' curiosity and engagement about learning a new language, reinforcing the idea that they are aware of the importance of their learning process regarding a foreign language and one of the justifications bring up their satisfaction for doing something they like and also towards the teacher.

These choices suggest that students enjoy learning the language, the teacher and that they have curiosity that might be a fuel to make them study and learn more and 
more, but even like this they do not seem to feel confident enough to speak English, maybe due to a matter of low self-esteem.

Table 3 brings only adjectives related to negative feelings associated with the moment learners have to speak English and the most mentioned one was "insecure". The justifications related to this word had the common point of lack of knowledge from the students towards English, its words and also compared to their fellow classmates and one of these reasons was related to the students' fear of other people's judgment which stops them to speak, a probable reflection of the absence of or low self-esteem.

Another adjective that was mentioned more than once was "shy" with students claiming in their justifications that they worry about their accents and not making themselves be understood by other people when they speak English. They also affirm that they do not speak the language well and that they are afraid of making mistakes, again reinforcing the idea of their lack of self-confidence due to low self-esteem.

The other mentioned adjectives ("anxious", "embarrassed", "nervous", “tense" and "uncomfortable") carry with them justifications that have the same essence as the previous ones, all referring to lack of knowledge, fear of making mistakes and of temporary forgetfulness of words, once more reflecting a probable lack of confidence due to low self-esteem.

\section{ACTIVITY 2}

Table 4 brings adjectives and comparatives that are related to positive feelings expressed by the students regarding the English language and their justifications for those choices might suggest the awareness the learners have in relation to the importance of learning the language, like, for example, when they say "because it is better for my future", "because it is good to be bilingual", "because I have an opportunity to learn another language and I love it", "because I am learning a new language and I like it" and "because it is another language and it is interesting" using the comparatives "as important as", "more important than", "more interesting than", and "smarter than".

Another situation that was brought up by the learners' justifications was the probable cognizance they have about the role the English language plays in the communication all over the world nowadays, when they use the following justifications: 
"because English is a universal language", "because some ' guys' in my country speak English", "because English is the second language of the world", "because you can communicate with the world", "because I want to visit other countries and talk to the foreigners" and "because it opened the world for me", related to the comparatives "more important than", "more interesting than" and "smarter than".

Finally, another point noticed in the learners' justifications was the comparisons they make between English and Portuguese (their L1), like for example, when they say "because English does not have a lot of verbs", "because English has less verb tenses", "because Portuguese grammar is very difficult", 'because studying Portuguese is boring but studying English is fun", "because Portuguese classes are boring", "because I already know words in Portuguese" and "because I already know Portuguese and it is boring", associated with the comparatives "easier than", "more fun than", "more interesting than" and "smarter than". These answers might show that students are satisfied with the fact that they are learning such an important language and they feel intelligent by doing so, thus these factors could not be considered a hindrance to their verbal communication process.

In table 5 we can see comparatives that are associated with more neutral feelings: "longer than" and "more practical than", and these choices are linked to justifications that are more related to technical issues that learners notice in the English language, such as "because English words are more difficult to understand", "because it is more objective" and "because the usual words that we use every day are short and easy to learn".

These elected adjectives/comparatives and their justifications might indicate that students know that the English language has its peculiarities in comparison with Portuguese but this fact does not interfere in their learning process nor it makes them feel inhibited to speak English.

Table 6 shows adjectives and comparatives associated with negative feelings the students have regarding the English language and the correspondent justifications to their choices. We can see the comparatives "as difficult as", "less comfortable than", "more difficult than", “more insecure than", “more uncomfortable than", "sadder than' and "shier than". 
The justifications vary from those that show the learners' difficulties with the language, as in "because I have a lot of difficulties in pronunciation", "because I have difficulty to understand and I have many doubts" and "because for me English is difficult" to the ones that compare English to Portuguese like "because there are a lot of details in the grammar", "because it is not my native language and the structure is different", "because Portuguese is my first language", "because the words in English are different and have a lot of meanings", "because there are many consonants in English", "because one word in English can have many meanings", "because there are many meanings for the same word", "because I speak Portuguese since I was young", as well as geographic differences, as in "because I was born in Brazil", "because I was born here" and "because it is not my language".

Other justifications were more associated with restrictions the students find in the language, such as "because I do not speak English very well", "because I forget a lot of things", "because I do not know the language", "because I do not try to talk to some people", "because I do not know English very well”, "because I cannot speak English very well after studying it for years", "because I do not speak well”, "because I am worried of making mistakes" and "because I am afraid of forgetting the words".

All these choices of adjectives and their respective justifications may suggest that students do not solely consider the structural differences between the languages as a trammel for them to learn and speak English, but also they are conscious about their difficulties due to shyness or another feeling that might diminish their self-esteem and consequently stops them to utter in English whenever they are supposed to do it.

Table 7 brings the students' justifications grouped in categories according to the similarities comprehended into these answers, in order to allow an easier and systematized analysis of the data.

The first topic is related to communication and the justifications associated with it were: "because I want to visit other countries and talk to foreigners", "because it opened the world for me", "because it brings a lot of opportunities to communicate with the world" and "because some 'guys' in my country speak English". These answers might indicate that the students recognize the importance of the English language regarding verbal expression for travelling matters or even for bringing them many 
different opportunities, but still they do not feel confident enough to speak when it is necessary.

The second topic is bound up to comparisons between the students' L1 (Portuguese) and English, involving their structures and geographical differences. The justifications that shared common points in this category were: "because Portuguese grammar is very difficult", "because studying Portuguese is boring but studying English is fun", "because Portuguese I already know and it is boring", "because Portuguese classes are boring", "because Portuguese is my first language", "because I was born in Brazil", "because I was born here", "because I speak Portuguese since I was young", "because I do not speak English very well”, "because I do not know English very well”, "because it is not my language", "because I already know words in Portuguese", "because it is different", "because for me English is difficult", "because I do not know the language" and "because I cannot speak English very well after studying it for years". These considerations suggest that students are aware that both languages have their differences but the learners could be using those differences as an excuse not to speak English whenever they are supposed to do it, even though considering Portuguese "difficult" and "boring" and English "fun".

The third topic is regarding the importance of English and the correlated justifications were: "because English is a universal language", "because English is the second language of the world", "because you can communicate with the world" and "because it is good to be bilingual". These answers propose that students do know the importance of the English language in order to have more opportunities to exchange impressions, goals and, of course, words with more and more people all over the world, yet they do not feel confident enough to do so.

The fourth topic is related to the language learning process and the correspondent justifications were: "because I am learning a new language", "because it is another language", "because I like studying both languages", "because I am learning a new language and I like it", "because I learn another language", "because I want to learn English", "because now I have a larger vocabulary", "because I always learn new topics" and "because I have an opportunity to learn another language and I love it". These answers might indicate that students enjoy learning a different language either because it enlarges their vocabulary or because they enjoy studying and learning new 
things, such as songs and cultural aspects of different countries that are part of the classes' contents, making them feel smarter, boosting their confidence and making them feel ready to speak English.

The fifth topic is about language structure and the correlated justifications were: "because English is more objective", "because there are a lot of details in the English grammar", "because I have difficulty to understand and I have many doubts", "because I have a lot of difficulty in pronunciation", "because English words are more difficult to understand", "because the usual words that we use every day are short and easy to learn", "because the words in English are difficult and have a lot of meanings", "because there are many consonants in English", "because one word in English can have many meanings" and "because there are many meanings for the same word".

These impressions shared by the students might indicate that some points in the English language's structure could be a hindrance to their learning process, especially when it comes to speaking, since the learners report they have difficulties in pronunciation, comprehension and learning the meaning for certain words or expressions. Thus, these issues should be debated between the learners and the teacher, in order to facilitate their learning process, making them feel more confident and consequently more able to speak.

The choice of adjectives, as well as the way the comparatives were formed and their respective justifications made me realize that the students find the language and the learning process interesting and, other than that, they are aware of the major role that the English language plays in their lives. Yet they feel insecure to express themselves especially verbally. This might indicate lack of confidence due to low selfesteem, a situation that could be overcome with the team work between teachers and students. 


\section{FINAL CONSIDERATIONS}

The growing importance of the English language in the world due to the advance of technology, the easier access to information and the raise in the number of passengers who travel abroad is dragging a growing number of English as a Foreign Language (EFL) students of different ages into classrooms all over the world. The real challenge for both students and teachers is having to deal with different backgrounds, beliefs and goals towards the English language. These factors might interfere in the moment when learners are supposed to communicate in the foreign language.

Before starting the "Especialização em Língua Inglesa" course at PUC-Rio in 2016, I have dealt with this situation many times in different groups that I teach at the English course where I work, but only after taking the subject Exploratory Practice (EP) with Professors Maria Isabel Cunha (Bebel) and Inés Miller it occurred to me that this difficulty of communicating in English the students had actually intrigued me and that I could come up with a puzzle to help me understand this situation better. And what was my surprise when I saw the engagement of the students in this process as well, because they felt like this issue also intrigued themselves and they were really pleased to participate in the Potentially Exploitable Pedagogic Activities that were used to help understanding, even if temporarily, this puzzle. This only corroborates what Allwright and Hanks (2009) had previously stated in their work, in the principles three, four and five of Exploratory Practice, which are:

- Principle 3: involve everybody

- Principle 4: Work to bring people together

- Principle 5: Work also for mutual development

Affect and feelings that are present in the learning process were also taken into consideration when I conducted this research paper, because according to Stevick (1980) apud Arnold (2009) "success in language learning depends less on materials, techniques and linguistic analyses and more on what goes on inside and between the people in the classroom", reinforcing what Scovel (2000) apud Arnold (2009) had stated, which is that emotions might represent the factor that most affects language learning. 
In accordance with the material gathered in the PEPAs, the learners are aware of the feelings they have during their learning process and how these feelings can interfere with their speaking process. This experience with Exploratory Practice was very satisfactory for both sides: the teacher, or me, because I discovered that we can use pedagogic activities to understand and eventually solve issues that are present at that moment in that environment, and also the students because it is a self-knowledge exercise disguised in a pedagogic activity, just like a group therapy session.

After taking the "Especialização em Língua Inglesa" course and getting to know Exploratory Practice, as well as the EP group that monthly meets at PUC-Rio, I became even more aware of how L2 teachers should take the learners' feelings into consideration when they plan their lessons. Furthermore, I was able to realize that the learning process can be a mutual collaboration between teachers and students and that life is a constant learning. Hopefully, the readers of this work can become aware of this as well. 


\section{REFERENCES}

ALLWRIGHT, D., HANKS, J. The Developing Language Learner: An Introduction to Exploratory Practice. Basingstoke: Palgrave Macmillan, 2009. 312 p.

ARNOLD, J. Affect in L2 learning and teaching. ELIA: Estudios de Linguística Inglesa Aplicada. No. 9, pp. 145-151, January 2009. Available at: https://www.researchgate.net/profile/Jane_Arnold2/publication/41763148_Affect_in_L 2_learning_and_teaching/links/546f57bf0cf216f8cfa9d783/Affect-in-L2-learning-andteaching.pdf?origin=publication_detail Accessed in June, 2018.

DÖRNYEI, Z. Motivation in Second Language Learning. In: CELCE-MURCIA, M., BRINTON, D. M. and SNOW, M. A. Teaching English as a second or foreign language. $4^{\text {th }}$ ed. Boston: National Geographic Learning/Cengage Learning, 2014. 681 p. Available at: https://docs.wixstatic.com/ugd/ba734f_538808efb77d4dc2abc402b2b9e53523.pdf?inde $\underline{x=\text { true }}$ Accessed in June, 2018.

HANKS, J. Exploratory Practice in Language Teaching: Puzzling about Principles and Practices. London: Palgrave Macmillan, 2017. 384 p.

LÓPEZ, M. G. M., AGUILAR, A. P. Emotions as Learning Enhancers of Foreign Language Learning Motivation. Profile: Issues in Teacher's Professional Development. Vol. 15, no. 1, pp. 109-124, 2013. Available at: https://revistas.unal.edu.co/index.php/profile/article/view/37872/40579 Accessed in June, 2018. 
MACINTYRE, P., GREGERSEN, T. Emotions that facilitate language learning: the positive-broadening power of the imagination. Studies in Second Language Learning and Teaching. Vol. 2, no. 2, pp. 193-213, 2012. Available at: https://pressto.amu.edu.pl/index.php/ssllt/article/view/5009/5229 Accessed in May, 2018.

NI, H. The Effects of Affective Factors in SLA and Pedagogical Implications. Theory and Practice in Language Studies, Vol. 2, No. 7, pp. 1508-1513, July 2012 Manufactured in Finland. Available at: https://pdfs.semanticscholar.org/8d1a/804def9080d8055ef2d673c00212eca4bde8.pdf/ Accessed on November 30, 2017.

RICHARDS, K. Qualitative Inquiry in TESOL. Basingstoke: PalgraveMacmillan, 2003. $322 \mathrm{p}$.

ROTHMAN, J.; SLABAKOVA, R. State of the Scholarship-The Generative Approach to SLA and its Place in Modern Second Language Studies. Studies in Second Language Acquisition, No. 40, pp. 1-26, 2017. Available at https://eprints.soton.ac.uk/406875/1/SSLA_to_appear.pdf Accessed n September, 2018.

SIMSEK, E.; DORNŸEI, Z. Anxiety and L2 Self-Images: the 'anxious self'. In: GKONOU, C.; DAUBNEY, J.; DEWAELE, J. M. New Insights into language anxiety: Theory, research and educational implications. Pp. 51-69. Bristol: Multilingual Matters, 2017. 248 p. Available at: https://docs.wixstatic.com/ugd/ba734f_9da3325c073c48e0a695bed9e7dd86ee.pdf?inde $\underline{\mathrm{x}=\text { true }}$ Acessed in April, 2018. 
SINGHAL, V. Chomsky's Theories on Language. February 3, 2012. Available at: http://www.brighthubeducation.com/language-learning-tips/71728-noam-chomskylanguage-acquisition-theories Accessed on November 28,2017.

VAN PATTEN, B.; ROTHMAN, J. In: REBUSCHAT, P. What does Current generative theory have to say about the explicit-implicit debate? Implicit and Explicit Learning of Languages. Amsterdam: John Benjamins Publishing Company, 2015. 489 p. Available on https://munin.uit.no/bitstream/handle/10037/article.pdf?sequence=1 Accessed on September, 2018. 